DOI https://doi.org/10.36059/978-966-397-159-9/1-17

\title{
ILLEGAL MIGRATION: CRIMINAL LEGAL SURVEY CONCEPTUAL ISSUES
}

\section{Natalya Orlovska}

\section{INTRODUCTION}

Migration issues have been always actualized for any of countries. In particular, during alone 2018: nearly 28 million people were forced to migrate due to military conflicts (10.8 million) and natural disasters (17.2 million $)^{1}$. EU countries and USA are mostly faced with external migration challenges - exactly in corresponding readout the social contradictions and political collisions become more evident.

The US example demonstrates haw precisely various migration issues are becoming a significant factor of current agenda. In this context especial attention is paid to crimes committed by migrants.

Many immigration advocates argue that immigrants have much lower crime rates than natives. The federal government does track the citizenship of those it convicts. Data from the U.S. Sentencing Commission shows that of those convicted of federal crimes between 2011 and 2016, 44.2\% were not U.S. citizens $-21.4 \%$, if immigration crimes are excluded. Non-citizens are $8.4 \%$ of the adult population. Of this $8.4 \%$ about $4 \%$ are illegal immigrants $^{2}$. Pursuant to Criminal history category and citizenship of offenders sentenced under immigration guidelines for 2017:non-U.S. citizens have committed 26799 crimes out of 66873 cases $^{3}$. In continuation of this: in $201826 \%$ of federal prisoners were aliens.

Migrant considered criminality trends have prompted a professional discussion concerning criminal justice system organization. Within those debates it was even suggested that the state and local prosecutors who have set up two systems of justice - a harsher one for citizens and a more lenient

1 Key Global Migration Figures, 2017 - 2019. URL: https://migrationdataportal.org/ sites/default/files/2019-08/key-global-migration-figures.pdf

${ }^{2}$ Camarota S.A. (2018) Non-Citizens Committed a Disproportionate Share of Federal Crimes, 2011-16. URL: https://cis.org/Camarota/NonCitizens-Committed-DisproportionateShare-Federal-Crimes-201116

${ }^{3}$ Immigration Data from the U.S. Sentencing Commission "Interactive Sourcebook of Federal Sentencing Statistics". URL: https://isb.ussc.gov/api/repos/:USSC:table_xx.xcdf/ generatedContent?table_num=Table49 
one for aliens - push ideas in order to "protect" alien criminals from what they view as the "excesses" of the administration's immigration policies ${ }^{4}$.

However, despite the fact that developed countries are the ultimate destination for migrants, the threats of illegal migration are more appreciable for developing countries because of they actually appear themselves as a certain temporary destination or transit element as a component of global migration processes. Therefore, these countries` costs share associated to this negative phenomenon is disproportionately increased ${ }^{5}$.That is why the problem of illegal migration, including especially its criminal legal aspect, is extremely important for Ukraine.

Criminal legal survey of illegal migration covers the whole problematic sphere of socially dangerous acts criminalization, punishments and other law measures that may be imposed for such acts committing. However, the analysis of contemporary criminal issues cannot be considered in isolation from the wider context.

\section{The initial provisions for illegal migration criminal legal survey}

The analysis of illegal migration in the context of criminal law requires definiteness relatively corresponding terminology. During recent years the international community has been moving away from using the term «illegal migration» simultaneously suggesting it to replace with «irregular migration» term.

International Organization for Migration (IOM) defines irregular migration as movement of persons that takes place outside the laws, regulations, or international agreements governing the entry into or exit from the State of origin, transit or destination ${ }^{6}$. The opposite concept is about regular (so-called, orderly) migration which is defined as the movement of a person from his/her habitual residence to a new place of residence, being a law abiding subject of the laws and departure regulation rules of country of origin and transit through/or entering on the territory of destination or transit country ${ }^{7}$.

\footnotetext{
${ }^{4}$ Arthur A.R. (2019) Are Criminal Aliens Above the Law? URL: https://cis.org/Arthur/ Are-Criminal-Aliens-Above-Law

${ }^{5}$ Ukrainske suspilstvo: mihratsiinyi vymir : natsionalna dopovid (2018) [Ukrainian society: migration survey : national report] Kyiv: Instytut demohrafii ta sotsialnykh doslidzhen im. M. V. Ptukhy NAN Ukrainy. P.137-138.

${ }^{6}$ Irregular migration URL:https://www.iom.int/key-migration-terms

${ }^{7}$ Mizhnarodna terminolohiia u sferi mihratsii: ukrainsko-anhliiskyi tlumachnyi slovnyk [International terminology in migration sphere: Ukrainian-English dictionary] Kyiv: BLANKPRES, 2015. P.8, 15.
} 
These terminological changes could be explained by the ontological negative sense of the «illegal migration» term, since it carries a criminal connotation and is seen as degrading to the migrant`s dignity ${ }^{8}$. However, the «illegal migration» term continues to be used in international circulation at the same time.

From our point of view the issue concerning extremely negative meaning for «illegal migration» definition is artificial by itself. In particular, the IOM emphasizes the unlawfulness of a person's actions to change his or her location: while it is unclear what practical importance an emphasis on adjective «irregular» or «illegal» has had.

What is about stigmatization of migrants as such then trying to solve or soften this problem through terminology changing is more like a departure from reality. Much more for migrants' dignity protection can be done by a well-considered state migration policy oriented on social integration.

Having taken into research consideration illegal migration as whole phenomenon there is absolutely naturally that, in addition to the national statistical data the practices of law enforcement and border guard institutions of the neighboring states, as well as the practices of interstate police forces are widely used. For example, there is possible to use various analytical data from the FRONTEX and FRAN (FRONTEX Risk Analysis Network) Annual Risk Analysis which assumes CIRAM (Common Integrated Risk Analysis Model) methodological approaches'.

One of the five main illegal migration routes is passed through the territory of Ukraine - the Central European route running through the Russian Federation, Ukraine, Poland and Slovakia to the countries of Western Europe ${ }^{10}$. For instance, Central Asian labour migrants try all possible ways to enter the Russian Federation or find other opportunities using facilitators for seeking asylum in the EU. If these migrants do not find a job in Kazakhstan or in Turkey, they use the Balkan, Ukraine and Belarus routes to reach the EU. Regional facilitators are typical for the eastern EU

${ }^{8}$ Mizhnarodna terminolohiia u sferi mihratsii: ukrainsko-anhliiskyi tlumachnyi slovnyk [International terminology in migration sphere: Ukrainian-English dictionary] Kyiv: BLANKPRES, 2015. P.15.

${ }^{9}$ Filippov S.O. (2019) Protydiia transkordonnii zlochynnosti: hlobalnyi kontekst $i$ realii Ukrainy: monohrafiia [Countering cross-border crime: the global context and realities of Ukraine] Odesa: Feniks. P.21.

10 Stratehiia intehrovanoho upravlinnia kordonamy na period do 2025 roku [2025 Integrated Border Management Strategy]: Approved by the Cabinet of Ministers of Ukraine on July 24, 2019 № 687-p. URL: https://zakon.rada.gov.ua/laws/show/687-2019-\%D1\%80 
border sections. Russian citizens were ranking first, followed by Belarusians and Ukrainians ${ }^{11}$.

FRONTEX data provides information on the irregular border crossing (IBC) of eastern border zone of the EU (2009-2017) that indicates the positive trends in Ukraine, which last worsened in $2016^{12}$, when Ukraine reported the highest number of detections followed by Latvia and Hungary.

Herewith 324 cases of illegal border-crossing were detected. More than three-quarters of detections took place at Ukrainian borders, involving mostly regional migrants, i.e. Ukrainians and Moldovans. Non-regional migrants (mostly citizens of Vietnam, Turkey and Iran) were detected in very low numbers ${ }^{13}$.

Thus, there are no significant difficulties when considering Ukraine as a country of origin and transit of illegal migrants. According to FRONTEX data only $0.2 \%$ of illegal migrants enter the EU collectively from the territories of Ukraine and Belarus. Consequently, the level of illegal migration of third-country nationals threat through the territory of Ukraine remains low ${ }^{14}$.

This gives for European countries the opportunity to redistribute resources and strengthen the counteraction to so-called secondary migration when migrants from non-EU countries move illegally between EU countries.

As significant factor in positive results achieving has became the active role of law enforcement institutions of Ukraine, first of all - the activity of the State Border Guard Service of Ukraine (SBGSU). Thus, in cases of state border illegal crossing by the efforts of SBGSU were detained: in 2016 1040 persons (88\% of them when attempting to leave Ukraine); in 2017 886 people (82\%); in $2018-1130$ (78\%); during 9 months in $2019-$ 830 people. Herewith for 9 months in 2019 being comparing to the same period in 2018 the number of foreigner refusals - potential illegal migrants -

\footnotetext{
${ }^{11}$ Migrant Smuggling Data and Research: A global review of the emerging evidence base, Volume 2 / edited by A. Triandafyllidou and M.L. McAuliffe; International Organization for Migration, Geneva, 2014. P.80

${ }^{12}$ Migrant Smuggling Data and Research: A global review of the emerging evidence base, Volume 2 / edited by A. Triandafyllidou and M.L. McAuliffe; International Organization for Migration, Geneva, 2014. P.76

${ }^{13}$ Eastern Partnership Risk Analysis Network Quarterly; Quarter 2. April-June 2016, Frontex. Warsaw. P.6, 7

${ }^{14}$ Mihratsiinyi profil Ukrainy za 2017 rik (2018) [Ukraine`s Migration Profile for 2017]. State Migration Service of Ukraine. URL: https://dmsu.gov.ua/assets/files/mig_profil/ migprofil_2017.pdf 
has increased in 1.5 times $^{15}$. The State Migration Service of Ukraine(SMSU) activity results in illegal migrants in the territory of Ukraine detecting can be recognized as significant ones: in 2016 there were 6390 persons; in 2017 9 678; in 2018 - 11 194; for 6 months in $2019-5780^{16}$. During 2018 alone: 249 groups of 1278 illegal migrants were identified by the National Police together with the SMSU and SBGSU ${ }^{17}$. At the same time, a large part of illegal migrants detection falls on the main educational regions of Ukraine where most foreigners traditionally live ${ }^{18}$.

This indicates the effectiveness increasing for prevention activities aimed on detecting and ending the offenses related to illegal migration.

But there is an increase in the number of migrants on legal entry channels, who (relying on the support of the Diasporas) formally try to get into Ukraine in order to remain here illegally or subsequently illegally enter the territory of the EU. Basically this confirms the tendency for so-called "delayed transit" when migrants formally legally enter the country (Ukraine) with an intention for further traveling abroad including through illegal means. However, the length of their staying in Ukraine does not have a fundamental importance.

In no case can it be argued that all or the vast majority of migrants who use legal routes to enter Ukraine are prone to commit crimes, aggravate the criminal situation and so on. However, in the case of considering Ukraine as a transit territory then migrants (sooner or later) become involved in illegal relations concerning to document forgery, illegal migration organization, human trafficking, smuggling etc.

Characteristic of migrants is the formation of Diasporas which role is ambivalent: on the one hand, in the Diasporas concrete migrant feels certain support and security, on the other - the Diaspora if not makes it impossible but significantly impedes the integration of migrants into current staying society. Although, viewing on the ultimate goal, the migrant is not very interested in such integration, but exactly this aspect enhances his

${ }^{15}$ Rezultaty operatyvno-sluzhbovoi diialnosti Derzhavnoi prykordonnoi sluzhby Ukrainy [The results of the operational and service activities of the State Border Guard Service of Ukraine]. URL: https://dpsu.gov.ua/ua/activity/ohorona-kordonu

${ }^{16}$ Rezultaty diialnosti Derzhavnoi mihratsiinoi sluzhby Ukrainy [The results of the activities of the State Migration Service of Ukraine]. URL: https://dmsu.gov.ua/diyalnist/ statistichni-dani/statistika-z-osnovnoj-diyalnosti.html

${ }^{17}$ U Natspolitsii tryvaie zahalnoderzhavna spetsoperatsiia «Mihrant» [National Migrant Special Operations Continues at National Police] URL: https://www.kmu.gov.ua/ua/news/unacpoliciyi-trivaye-zagalnoderzhavna-specoperaciya-migrant

18 Ukrainske suspilstvo: mihratsiinyi vymir : natsionalna dopovid (2018) [Ukrainian society: migration survey : national report] Kyiv: Instytut demohrafii ta sotsialnykh doslidzhen im. M. V. Ptukhy NAN Ukrainy. P.14, 333. 
victimization. Actually, it is highly likely that such persons are able to become the victims of criminal offenses including fraud by so-called "traffickers" among which are available illegal migrants themselves.

Given this the inclusion of illegal migration studies into the more general security discourse and the migration dimension of national security separation along with economic, social, environmental aspects, etc. should be supported.

At the same time, the confrontation between the interests of the individual and the society is inappropriate, and national and migrant security must be united in order to reaching a common goal - to reduce the volumes of illegal migration through transferring their flows into the legal sphere ${ }^{19}$.

Precisely in the security context the issues of state migration policy are considered today - among its legal instruments the prominent position belongs to criminal legal influence.

\section{The place and role of criminal legal influence in the state migration policy of Ukraine}

The state migration policy of Ukraine development has been strategically formalized after the Strategy of the state migration policy of Ukraine for the period up to 2025 adoption. Such program of actions reflected the modern European approaches in this sphere. In particular, the approaches that define and shape migration policy include the expulsion of illegal migrants and the legal status adjustment for those persons who cannot be excluded according to humanitarian grounds. At the same time the law enforcement approach retains its importance and plays a leading role. It is aimed at strengthening migration control to identify and neutralize organized structures in the sphere of illegal migration and trafficking in human beings organizing.

Thus, Ukraine demonstrates progress in the framework of pan-European migration policy bringing the issues of non-repressive methods of migration processes regulation to the fore. With regard to combating illegal migration this indicates an attempt to respond concerning challenges and threats by outstripping offenses in migration sphere.

However, establishing responsibility for offenses in the migration field remains in the focus of prevention activity. This is explicitly stated in the Strategy of the State Migration Policy of Ukraine for the period up to 2025 as a direction of the mentioned policy determining - strengthening of responsibility for offenses in the migration field.

19 Ukrainske suspilstvo: mihratsiinyi vymir : natsionalna dopovid (2018) [Ukrainian society: migration survey : national report] Kyiv: Instytut demohrafii ta sotsialnykh doslidzhen im. M. V. Ptukhy NAN Ukrainy. P. 136, 138. 
Pay attention that there is no direct designation precisely on criminal responsibility installation establishing. And speaking about national legal system then administrative responsibility is established first of all for the offenses in the migration sphere. In particular, it is about:

delicts of illegal migrants (for example, violation of staying in Ukraine and transit through the territory of Ukraine rules by foreigners and stateless persons; illegal crossing or attempting to cross illegally the state border of Ukraine);

delicts of Ukrainian citizens aimed on illegal migrants facilitating (failure to take measures to ensure timely registration of foreigners and stateless persons; violation of the rules of foreigners and stateless persons housing and vehicles providing, and other services facilitating provision; foreigners and stateless persons illegal transfer through the territory of Ukraine).

However, the most socially dangerous acts are criminalized, in particular, viewing on international commitments concluded by Ukraine in the sphere of illegal migration as a type of transnational crime preventing. The main document in this area is Protocol against the Smuggling of Migrants by Land, Sea and Air, supplementing the United Nations Convention against Transnational Organized Crime to which Ukraine has been a party since $2004^{20}$.

According to international standards Ukraine has found as out of criminal legal to smuggle persons across the state border. In addition, criminal liability for related acts including the creation of a criminal organization, forgery of documents, etc., has been established.

According to Art. 6 of the Protocol against the Smuggling of Migrants by Land, Sea and Air: the legislative measures as may be necessary to establish as aggravating circumstances to the offences established in accordance the lives or safety of the migrants concerned; or entail inhuman or degrading treatment including for such migrants exploitation - have to be adopted by State. These obligations were fulfilled by Ukraine in establishing criminal liability for more serious cases of persons transfer across the state border.

Therefore, it cannot be argued that the importance of criminal legal influence in state migration policy is exaggerated in Ukraine. It seems that the state uses criminal instruments fairly moderately - only in cases when other legal remedies cannot solve the problem of illegal migration preventing.

${ }^{20}$ United Nations Convention against Transnational Organized Crime and the Protocols Thereto / UNODC. Vienna URL: https://www.unodc.org/documents/middleeastandnorthafrica/ organised-crime/united_nations_convention_against_transnational_organized_crime_and_the_ protocols_thereto.pdf 
As noted above, developing countries are more affected by illegal migration than developed countries. This raises the question about the expediency of establish criminal liability or punishment increasing for certain socially dangerous acts.

It seems that the point-to-point application of criminal legal influence in the context of state migration policy also appears to be due to the fact that the costs of illegal migration combating are not only direct costs but also include expenses for reputational issues (protection of human rights and freedoms, organization of law enforcement agencies and judicial system, etc.).

Against this background it should be recognized that criminal legal influence is the most costly part of illegal migration preventing activity. That is why the requirements to the quality of criminal law and enforcement in this part are so important.

\section{The issues of criminal influence for crimes related to illegal migration}

The XIII United Nations Congress on Crime Prevention and Criminal Justice devoted to crime issues particularly emphasized the danger of transnational crime various forms that adversely affect the sustainable development of society. Among the most socially dangerous manifestations affecting the interests of many countries is the illegal import (smuggling) of migrants ${ }^{21}$.

However, this position mainly reflects the situation in the recipient countries: illegal export and transit of migrants are no less as the problems. The manifestations of illegal migration have become the result of globalization processes when criminal activity was distributed in the world, has been formatted a "criminal map" which illustrates the regularities of the criminal processes interconnection. In addition to the global survey the regional is also important one. In the European context, in particular, this is manifested in the unilateral direction of illegal migration routes (from East to West).

The criminal survey of illegal migration correlates with the criminological nature of socially dangerous acts in this sphere: on the one hand, it is a relatively independent group of crimes, on the other - it is a background phenomenon that aggravates the criminal situation in the country.

Investigation of the criminological nature of these crimes allows us to distinguish the features of migration crimes that are embodied in criminal law. These features include:

${ }^{21}$ XIII United Nations Congress on Crime Prevention and Criminal Justice (Doha, 12-19 April 2015) URL: http://www.un.org/ru/events/crimecongress2015 
1. Transnationality / transborderness of separate action and socially dangerous activities by and large.

Article 3 of the United Nations Convention against Transnational Organized Crime gives off 4 features of a transnational crime, the presence of at least one of which provides grounds to classify the act as transnational one:

it is committed in more than one State;

it is committed in one State but a substantial part of its preparation, planning, direction or control takes place in another State;

it is committed in one State but involves an organized criminal group that engages in criminal activities in more than one State;

it is committed in one State but has substantial effects in another State ${ }^{22}$.

A separate type of transnational crimes is transborder criminal activity which is directly related to the state border crossing. It is obvious that manifestations of illegal migration in the criminal legal survey are crossborder crimes since in the process of their committing there is a physical movement of persons across the state border.

However, criminal law does not always clearly identify the signs of a transnational / transborder crime. It seems that in determining such a crime there is supposedly to proceed not only from the normative definitions but also from its objective characteristics.

Thus, if the objective side of a crime involves actions related to moving across a state border then such crime can be considered as transnational / transborder one.

Therefore, criminalized manifestations in the sphere of illegal migration are transnational / transborder acts, and basically - illegal migration is an amplitutious transnational negative phenomenon affecting the interests of more than one state.

Exactly as a type of transborder crime the illegal migration is closely linked to human trafficking, smuggling of weapons, ammunition, explosives and drugs, transnational corruption and international terrorism.

2. Economic nature which determines the shadow business kind formation in the sphere of illegal migration.

At the current stage the transnational / transborder crime is economic in its nature. This thesis is obvious when considering the crimes related to the movement of goods / items / information. In such a case the main factor that

${ }^{22}$ United Nations Convention against Transnational Organized Crime and the Protocols Thereto / UNODC. Vienna URL: https://www.unodc.org/documents/middleeastandnorthafrica/ organised-crime/united_nations_convention_against_transnational_organized_crime_and_ the_protocols_thereto.pdf 
determines the development of criminal activity is the different profitability of economic transactions in the territories on both sides of the state border: by using the economic situation in these territories criminals receive a financial gain. However, when it comes to crimes related to illegal migration then it is important to recognize that there are more complex economic levers.

Crime activity in illegal migration sphere is a shadow business with a complex structure consisted of:

economic activity related to the transit of migrants across borders; concerning its profitability the involvement of the around-the-border residents in such displacement processes indicates (for example, according to the press service of the Security Service of Ukraine in Lviv region, in April 2019 a citizen of Ukraine - a migrant smuggler was detained upon receipt of $\$ 1$ thousand);

economic activity related to the exploitation of illegal migrants in Ukraine; in such cases the citizens of Ukraine are trying to use the work of illegal migrants who are attempting to earn costs for further cross-border crossing. In particular, the story of 28 migrants from Vietnam revealed in October 2018 in the Glevakha village, Kyiv region, where they were held in slavery for three months ${ }^{23}$.

Accumulation of shadow income from illegal migration plays an ambivalent role:

on the one hand, significant financial resources in this sphere allow economic agents to influence on the socio-political situation (at least in the border regions). In particular, law enforcement agencies may be restricted in carrying out certain preventive measures because of the resistance of the population interested in the shadow business;

on the other side, these revenues become a vulnerable place in criminal schemes because their disclosure makes it possible to identify not only individual carriers, but whole criminal groups as well. Thus, the XIII United Nations Congress on Crime Prevention and Criminal Justice emphasized that combating the illegal importation of migrants (smuggling of migrants) involves conducting financial investigations to track the revenue of criminal groups.

\section{Organized nature.}

Because of illegal migration presents itself a shadow transnational / transborder business then there must be recognized that it can exist only as

${ }^{23}$ Erman G. (2018) Skil'ky nelehaliv khoche potrapyty do ES z Ukrayiny i shcho z nymy stayet'sya [How many illegals want to get to the EU from Ukraine and what happens to them] URL: https://www.bbc.com/ukrainian/features-50220375 
organized activity since organized nature is inherently considered for business practice. However, in the context of crime it is a criminal activity form - organized crime as an activity of persistent criminal groups focused on obtaining the maximum income spending the minimum of time. The "organization" in relation to illegal migration actually reflects the unity of the shadow business and the criminal groups involved in it.

In the context of traditional view the criminal groups are organized groups and criminal organizations. However, the organizational level of criminals involved into smuggling migrants processes can vary enough significantly. In this sphere there are not only mafia type groups of a with a hierarchical structure, but also less rigidly built crime networks each of which plays a certain role at different stages of the migrants smuggling. Basically according to experts` opinion, than further then more important becomes the networks role that arises and cooperates with each other based on market forces in an effort to make a profit ${ }^{24}$.

Thus, the economic actors involved in the shadow business of illegal migrants displacing are very diverse ones. At one end of the scale are the (irregular) migration agents, who maybe legitimate travel or migration agents providing lawful services to travellers/migrants, with perhaps occasional assistance to those seeking to travel irregularly (such as fraudulent documents, contacts and information/advice). At the other end of the spectrum are the "apex" smugglers/traffickers, who oversee sophisticated transnational criminal syndicates and networks that deal with large-scale operations, often involving different types of smuggling and/or trafficking ${ }^{25}$.

However, it is worth mentioning about even more threatening situation the massive involvement of the border regions residents into such activity with amorphous groups without a defined structure formation.

Thus, illegal migration is a kind of shadow business and a component of transnational / transborder organized crime. At the same time it plays a role of a favorable basis for the deterioration of the criminal situation in the country, the "entering" into the territory of Ukraine of transnational criminal groups and so on. In this context illegal migration is a purely negative phenomenon the existence of which requires the prevention of mostly compulsory measures - by criminal legal ones.

24 Mezhdunarodnaya platforma deystviy $v$ tselyakh vypolneniya Protokola protiv nezakonnogo vvoza migrantov (2012) [International Platform for the Implementation of the Protocol against the Smuggling of Migrants] / UNODC. Vena. P.3, 6.

${ }^{25}$ Facilitating migration and fulfilling rights - to reduce smuggling of migrants and prevent trafficking in persons. 4-5 September 2017, Vienna. URL: https://refugeesmigrants.un.org/sites/ default/ files/ts5_gaatw.pdf 
First of all, it should be noted that the Criminal Code of Ukraine does not have definitions or signs of transnational /transborder crime. However, both the textual and contextual criminal legislation prescribe responsibility for such crimes including those of them related to illegal migration.

Thus, in the Common part of the Criminal Code of Ukraine there are provisions on the place of crime committing (Article 6). They regulate the rules of the criminal legislation of Ukraine application for crimes the process of which committing involves at least two states - respectively, such acts fall under the jurisdiction of such states. Other provisions of the Common Part refer, more likely, to procedural aspects for other states sentences recognition or the offenders extradition.

For this reason the illegal migration related crimes fall under the jurisdiction of Ukraine if they were initiated, continued, finished or terminated in the territory of Ukraine. Accordingly, at any stage of the intent realization a person who illegally moves people across the border or crosses a state border in violation of a criminal legal prohibition may be held criminally liable.

In the Special Part of the Criminal Code of Ukraine the acts related to illegal migration are not limited to the crime of "Illegal Transfer of Persons across the State Border of Ukraine". Let us pay attention to the act that was criminalized in connection with the Russian aggression against Ukraine "Illegal Crossing of the State Border of Ukraine". In addition, Article 149 provides for criminal liability for human traffic. Although the acts that constitute the structure of human traffic may also be committed on the territory of Ukraine the practice testifies to the predominantly transborder nature of this crime.

Therefore, criminal legal manifestations of illegal migration are covered by Articles 332 "Illegal Transfer of Persons across the State Border of Ukraine", 332-2 "Illegal Crossing of the State Border of Ukraine", 149 "Human Traffic".

What is the difference between the illegal transfer of persons across the state border and the illegal crossing of the state border? It seems that the following conclusions can be drawn:

the criminal liability establishing for the illegal transfer of persons across the state border is the embodiment of Ukraine's international obligations in accordance to United Nations Convention against Transnational Organized Crime and the Protocol against the Smuggling of Migrants by Land, Sea and Air; criminal responsibility for illegal crossing of the state border is a means of national security of Ukraine protection in the conditions of armed aggression; 
contextually criminal-punishable transfer of persons across the state border is the import and export of illegal migrants to / from the territory of Ukraine; out of criminal law crossing of the state border is exactly entry into Ukraine;

the subject of the illegal transfer of persons across the state border is the person who transports, organizes or facilitates the illegal migrant to enter Ukraine or another state, that is, the subject of this crime is not the illegal migrant himself; the subject of the illegal crossing of the state border is the migrant himself;

the subject of illegal transfer of persons across the state border in most cases pursues mercenary motives (although an indication of a moneymaking motive is presented only in part 3 of Article 322); the subject of illegal crossing of the state border has already had problems with the law (the person who is forbidden to enter the territory of Ukraine), or is trying to cause damage to the national security of Ukraine.

Thus, the vision of illegal migration as a type of transnational / transborder shadow business which is characterized by organized forms of activity does not cover the illegal crossing of the state border, because this activity is predominantly political by nature. However, it is seen that in the commission of this crime the person forbidden to enter the territory of Ukraine does not exclude the attempt in the future to illegally leave the territory of Ukraine in the western direction through intermediaries. That is, the subject of illegal crossing of the state border "turns" into the person involved in illegal crossing across the state border.

With regard to in human traffic this crime (in the case of the victim being moved across the state border) is a part of the criminal survey of illegal migration. What is concerning the facts of human trafficking registered in Ukraine then more than $75 \%$ of them are transborder acts.

Legislation on criminal liability for human traffic meets international standards in this sphere. In particular, the punishment for committing a crime against a child, in the case of violence, by organized crime structures, etc is being increased. The issue of exploitation of victims of human traffic which provides for a wide range of offenders acts in this area is enough regulated in details.

At the same time attention should be paid to the perspectives for the development of criminal legal prevention of crime committing related to illegal migration. First of all, it seems appropriate to raise the issue of the criminal influence on legal entities regulation which is important in view of the increasing in recent years of humanitarian non-State actors who may unintentionally be assisting organized criminal smuggling networks, such as 
those involved in the development of apps to help irregular migrants travel ${ }^{26}$. The world community appeals to develop strategies to prevent and combat all illicit financial flows and emphasize the urgent need to adopt more effective measures to fight against economic and financial crimes, including fraud, as well as tax and corporate crimes, especially in their relevant transnational dimensions ${ }^{27}$.

In particular, it is expedient to expand the list of crimes in which criminal measures can be applied to legal entities at the expense of actions related to illegal migration. Furthermore, the socially dangerous activities of legal entities are by their nature purely economic and the criminal legal response to such activity should be specific.

It is also evident that it is advisable to displace preventive action towards the detection of criminal structures engaged in the organization of illegal migration, to establish links between different sections of criminal networks "responsible" for different stages of criminal activity. In particular, it is a necessity when investigating and prosecuting offences related to trafficking in persons and the smuggling of migrants, the concurrent undertaking financial investigations, with a view to tracing, freezing and confiscating proceeds acquired through those crimes, and the establishment of such crimes as predicate offences for money-laundering, as well as to enhance coordination and information-sharing among relevant agencies ${ }^{28}$.

Enforcement policy improving is also an important aspect as the courts today have a rather lenient attitude towards persons who commit crimes related to illegal migration. This is especially clearly manifests itself when punishing the human traffic. As the analysis has showed the courts mostly release offenders from punishment what does not facilitate crime prevention in the future.

\section{CONCLUSIONS}

The above allows to resume that illegal migration as a whole is a negative consequence of globalization, and that its features (directions, distribution of countries into donors, transiters and recipients) embody the regional specificity of certain territories. Herewith developing countries suffer more from illegal migration than countries which receive migrants.

\footnotetext{
${ }^{26}$ Facilitating migration and fulfilling rights - to reduce smuggling of migrants and prevent trafficking in persons. 4-5 September 2017, Vienna. URL: https://refugeesmigrants.un.org/ sites/default/files/ts5_gaatw.pdf

27 XIII United Nations Congress on Crime Prevention and Criminal Justice (Doha, 12-19 April 2015) URL: http://www.un.org/ru/events/crimecongress2015

28 XIII United Nations Congress on Crime Prevention and Criminal Justice (Doha, 12-19 April 2015) URL: http://www.un.org/ru/events/crimecongress2015
} 
Establishing responsibility for migration offenses is part of the state's current migration policy. Criminal liability is advisable to be provided concerning the most socially dangerous acts.

Studies of the illegal migration criminal legal survey show that its manifestations are embodied in crimes characterized by transnationality / transborderness, economic character, organizational structureness. At the present stage crimes related to illegal migration are a kind of shadow business. In addition, illegal migration acts as a background phenomenon facilitating the committing of various crimes by and against migrants themselves.

The subjective composition of socially dangerous acts testifies to the negative role of legal entities through or under the cover of which criminals are active. In addition, there is involvement of broad groups of the residents from around-the-border areas into criminal activity by forming stable antisocial ties between citizens of different countries, organizing corruption schemes with the authorities of neighboring states representatives' participation.

\section{SUMMARY}

The article is devoted to the illegal migration criminal legal survey. There is concluded that illegal migration prevention has to be an essence of state migration policy of Ukraine in terms of responsibility for migration offenses increasing.

There is found out that in the criminal legal survey the illegal migration is represented by crimes the specific features of which are transnationality / transborderness, economic character, organizational structureness. These crimes are referred in such articles of the Criminal Code of Ukraine: 332 "Illegal Transfer of Persons across the State Border of Ukraine", 332-2 "Illegal Crossing of the State Border of Ukraine", 149 "Human Traffic".

At the present stage crimes related to illegal migration form a kind of shadow business which is carried out not only by organized criminal organizations, but also by legal entities. This business also has a broad involvement of the around-the-border residents.

Perspectives for the development of such crimes criminal legal prevention are in improving the impact on legal entities and investigating concerning crimes that facilitate the processes of illegal migration (in particular, money laundering). 


\section{REFERENCES}

1. Key Global Migration Figures, 2017 - 2019. URL: https://migrationdataportal.org/sites/default/files/2019-08/key-globalmigration-figures.pdf

2. Camarota S.A. (2018) Non-Citizens Committed a Disproportionate Share of Federal Crimes, 2011-16. URL: https://cis.org/Camarota/ NonCitizens-Committed-Disproportionate-Share-Federal-Crimes-201116

3. Immigration Data from the U.S. Sentencing Commission "Interactive Sourcebook of Federal Sentencing Statistics". URL: https://isb.ussc.gov/api/ repos/:USSC:table_xx.xcdf/generatedContent?table_num=Table49

4. Arthur A.R. (2019) Are Criminal Aliens Above the Law? URL: https://cis.org/Arthur/Are-Criminal-Aliens-Above-Law

5. Ukrainske suspilstvo: mihratsiinyi vymir : natsionalna dopovid (2018) [Ukrainian society: migration survey : national report] Kyiv: Instytut demohrafii ta sotsialnykh doslidzhen im. M. V. Ptukhy NAN Ukrainy. 396 p. (in Ukrainian)

6. Irregular migration. URL: https://www.iom.int/key-migration-terms

7. Mizhnarodna terminolohiia u sferi mihratsii: ukrainsko-anhliiskyi tlumachnyi slovnyk [International terminology in migration sphere: Ukrainian-English dictionary] Kyiv: BLANK-PRES, 2015. 100 p. (in Ukrainian)

8. Filippov S.O. (2019) Protydiia transkordonnii zlochynnosti: hlobalnyi kontekst $i$ realii Ukrainy: monohrafiia [Countering cross-border crime: the global context and realities of Ukraine] Odesa: Feniks. 452 p. (in Ukrainian)

9. Stratehiia intehrovanoho upravlinnia kordonamy na period do 2025 roku [2025 Integrated Border Management Strategy]: Approved by the Cabinet of Ministers of Ukraine on July 24, 2019 № 687-p. URL: https://zakon.rada.gov.ua/laws/show/687-2019-\%D1\%80 (in Ukrainian)

10. Migrant Smuggling Data and Research: A global review of the emerging evidence base, Volume 2 / edited by A. Triandafyllidou and M.L. McAuliffe; International Organization for Migration, Geneva, 2014. 228 p.

11. Eastern Partnership Risk Analysis Network Quarterly; Quarter 2. April-June 2016, Frontex. Warsaw. 17 p.

12. Mihratsiinyi profil Ukrainy za 2017 rik (2018) [Ukraine`s Migration Profile for 2017]. State Migration Service of Ukraine. URL: https://dmsu.gov.ua/assets/files/mig_profil/migprofil_2017.pdf (in Ukraine)

13. Rezultaty operatyvno-sluzhbovoi diialnosti Derzhavnoi prykordonnoi sluzhby Ukrainy [The results of the operational and service activities of the State Border Guard Service of Ukraine]. URL: https://dpsu.gov.ua/ua/ activity/ohorona-kordonu (in Ukraine) 
14. Rezultaty diialnosti Derzhavnoi mihratsiinoi sluzhby Ukrainy [The results of the activities of the State Migration Service of Ukraine]. URL: https://dmsu.gov.ua/diyalnist/statistichni-dani/statistika-z-osnovnojdiyalnosti.html (in Ukraine)

15. U Natspolitsii tryvaie zahalnoderzhavna spetsoperatsiia "Mihrant» [National Migrant Special Operations Continues at National Police] URL: https://www.kmu.gov.ua/ua/news/u-nacpoliciyi-trivaye-zagalnoderzhavnaspecoperaciya-migrant (in Ukraine)

16. United Nations Convention against Transnational Organized Crime and the Protocols Thereto / UNODC. Vienna URL: https://www.unodc.org/ documents/middleeastandnorthafrica/organised-crime/united_nations_ convention_against_transnational_organized_crime_and_the_protocols_ther eto.pdf

17. XIII United Nations Congress on Crime Prevention and Criminal Justice (Doha, 12-19 April 2015) URL: http://www.un.org/ru/events/ crimecongress 2015

18. Erman G. (2018) Skil'ky nelehaliv khoche potrapyty do ES z Ukrayiny $i$ shcho $z$ nymy stayet'sya [How many illegals want to get to the EU from Ukraine and what happens to them] URL: https://www.bbc.com/ukrainian/ features-50220375 (in Ukraine)

19. Mezhdunarodnaya platforma deystviy $v$ tselyakh vypolneniya Protokola protiv nezakonnogo vvoza migrantov (2012) [International Platform for the Implementation of the Protocol against the Smuggling of Migrants] / UNODC. Vena. 180 p. [in Russian]

20. Facilitating migration and fulfilling rights - to reduce smuggling of migrants and prevent trafficking in persons. 4-5 September 2017, Vienna. URL: https://refugeesmigrants.un.org/sites/default/files/ts5_gaatw.pdf

\section{Information about the author: \\ Natalya Orlovska,}

Doctor in Law, professor,

Head of the Department of Criminal Law and Procedure, National Academy of the state Border Guard of Ukraine named after Bogdan Khmelnitsky 46 Schevchenko str., Khmelnitsky, Ukraine, 29001 ORCID ID: orcid.org/0000-0002-4400-560X 